\author{
A. Sitko ${ }^{1}$, M. Szkodo ${ }^{1}$, S. Kucharski ${ }^{2}$ \\ ${ }^{1}$ Gdańsk University of Technology, Faculty of Mechanical Engineering, Department \\ of Materials Technology and Welding, 11/12 Narutowicza, 80-233 Gdańsk, Poland \\ artursitko@o2.pl \\ ${ }^{2}$ Institute of Fundamental Technological Research of the Polish Academy of Sciences, \\ Department of Mechanics of Materials, Pawińskiego 5B, 02-106 Warsaw, Poland
}

\title{
INFLUENCE OF NITRIDING AND LASER REMELTING ON PROPERTIES OF AUSTENITIC STAINLESS STEEL TYPE X10CrNi18-8 AND CAVITATION EROSION RESISTANCE
}

\begin{abstract}
The paper presents properties of surface layers. Surface layers were obtained by using low temperature glowdischarge nitriding process and laser remelting carried out on austenitic stainless steel type X10CrNi18-8. Investigations were done by using an Ultra Nanoindentation Tester (UNHT) in the Warsaw Institute of Fundamental Technological Research. The influence of the above mentioned treatments on obtained surface layers is shown. The values of the Vickers hardness $(\mathrm{HV})$, the irreversible indentation work $\left(\mathrm{W}_{\text {ir }}\right)$, the reversible work $\left(\mathrm{W}_{\mathrm{e}}\right)$ and the maximum depth $\left(\mathrm{h}_{\max }\right)$ during indentation were determined using the method proposed by Oliver and Pharr [1]. On the basis of mechanical properties, the elasticity $\left(\mathrm{I}_{\mathrm{e}}\right)$ and ductility $\left(\mathrm{I}_{\mathrm{ir}}\right)$ indexes were calculated. Moreover, microstructure cross-section of the austenitic stainless steel after nitriding process and laser remelting was observed using a scanning electron microscope. Cavitation test was performed at a vibratory rig with stationary specimen. On the basis of erosion curves the cavitation resistance was evaluated.
\end{abstract}

Keywords: glow-discharge nitriding process, laser remelting, austenitic stainless steel, diffusion layer, nitrided case, expanded austenite

\section{INTRODUCTION}

Nowadays, a great deal of attention in research works is focused on low temperature glow-discharge nitriding process and laser remelting of austenitic stainless steels. The usefulness of analyses of these technologies results from the fact that they could improve mechanical properties of austenitic stainless steels without decreasing their excellent corrosion resistance. After laser remelting, the chemical composition of alloys is homogeneous due to dissolution of precipitates. In papers [2-6] it was confirmed that the laser remelting showed a beneficial influence on corrosion resistance of austenitic stainless steels. Additionally, the low temperature nitriding process (about $450{ }^{\mathrm{O}} \mathrm{C}$ ) can also lead to improvement of corrosion resistance. During the nitriding process the temperature is the most important parameter which can lead to separation from a solution of chromium nitrides. This may result in a significant decrease of corrosion resistance of austenitic stainless steels. References [7-16] prove that nitriding process has a beneficial effect on corrosion resistance of austenitic microstructure in relatively low temperatures. 


\section{EXPERIMENTAL}

\section{Nitriding process}

The parameters of glow-discharge nitriding process of the austenitic stainless steel type X10CrNi18-8 are presented in table 1. During the nitriding processes various chemical compositions of gas mixture were applied. All treatments were conducted on test specimens of $20 \mathrm{~mm}$ diameter and $6 \mathrm{~mm}$ height.

Table 1. Parameters of low temperature glow-discharge nitriding process

\begin{tabular}{|c|c|c|c|c|c|}
\hline \multirow{3}{*}{$\begin{array}{c}\text { No. } \\
\text { of process }\end{array}$} & \multirow{3}{*}{$\begin{array}{c}\text { Time } \\
{[\mathrm{h}]}\end{array}$} & \multirow{3}{*}{$\begin{array}{c}\text { Pressure } \\
{[\mathrm{hPa}]}\end{array}$} & \multirow{3}{*}{$\begin{array}{c}\text { Temperature } \\
{\left[{ }^{\circ} \mathrm{C}\right]}\end{array}$} & \multicolumn{2}{|c|}{ Chemical composition } \\
\hline & & & & $\mathrm{N}_{2}$ & $\mathrm{H}_{2}$ \\
\hline & & & & \multicolumn{2}{|c|}{ [\% wt.] } \\
\hline 1 & 6 & 4.0 & 450 & 10 & 90 \\
\hline 2 & 6 & 4.0 & 450 & 70 & 30 \\
\hline
\end{tabular}

Laser treatment was conducted using the TRUMPF TLF 6000 turbo $\mathrm{CO}_{2}$ laser at Kielce University of Technology. The parameters of laser remelting process are presented in table 2 . Various power of the laser beam was applied. During the laser remelting the test specimens were immersed in liquid nitrogen and inert gas was delivered at the same time.

Table 2. Parameters of laser remelting process

\begin{tabular}{|c|c|c|c|c|c|}
\hline $\begin{array}{c}\text { No. } \\
\text { of process }\end{array}$ & $\begin{array}{c}\text { Power } \\
{[\mathrm{kW}]}\end{array}$ & $\begin{array}{c}\text { Scanning } \\
\text { velocity } \\
{[\mathrm{m} / \mathrm{min}]}\end{array}$ & $\begin{array}{c}\text { Laser beam size } \\
{[\mathrm{mm}]}\end{array}$ & $\begin{array}{c}\text { Cooling } \\
\text { medium }\end{array}$ & $\begin{array}{c}\text { Inert } \\
\text { gas }\end{array}$ \\
\hline $1 \mathrm{a}$ & 2 & 0.25 & $1 \times 20$ & $\begin{array}{c}\text { Liquid } \\
\text { nitrogen }\end{array}$ & Argon \\
\hline $1 \mathrm{~b}$ & 5 & 0.25 & $1 \times 20$ & $\begin{array}{c}\text { Liquid } \\
\text { nitrogen }\end{array}$ & Argon \\
\hline
\end{tabular}

\section{Microstructure of the reference material and nitrided cases}

In fig. 1 microstructure of the reference material and nitrided layer after the nitriding process no. 1 is shown. The microstructure of the reference material consists of the austenite phase $(\gamma)$ and a small amount of the delta ferrite phase. In an enlarged excerpt of the bigger picture, the microstructure of the nitrided layer is shown. Ferrite phase is not observed in the diffusion layer. In case of nitrided layers after the process no. 1, microcracks and deformations caused by twinning or by slip are not observed. In nitrided layers obtained after the process no. 2, above mentioned effects were observed (Fig. 2). In Fig. 2 microcracks and slip bands in the nitrided layer as a result of higher inner stresses are shown. Moreover, after the process no. 2, some microcracks were observed in the region between the base material and the diffusion layer. 


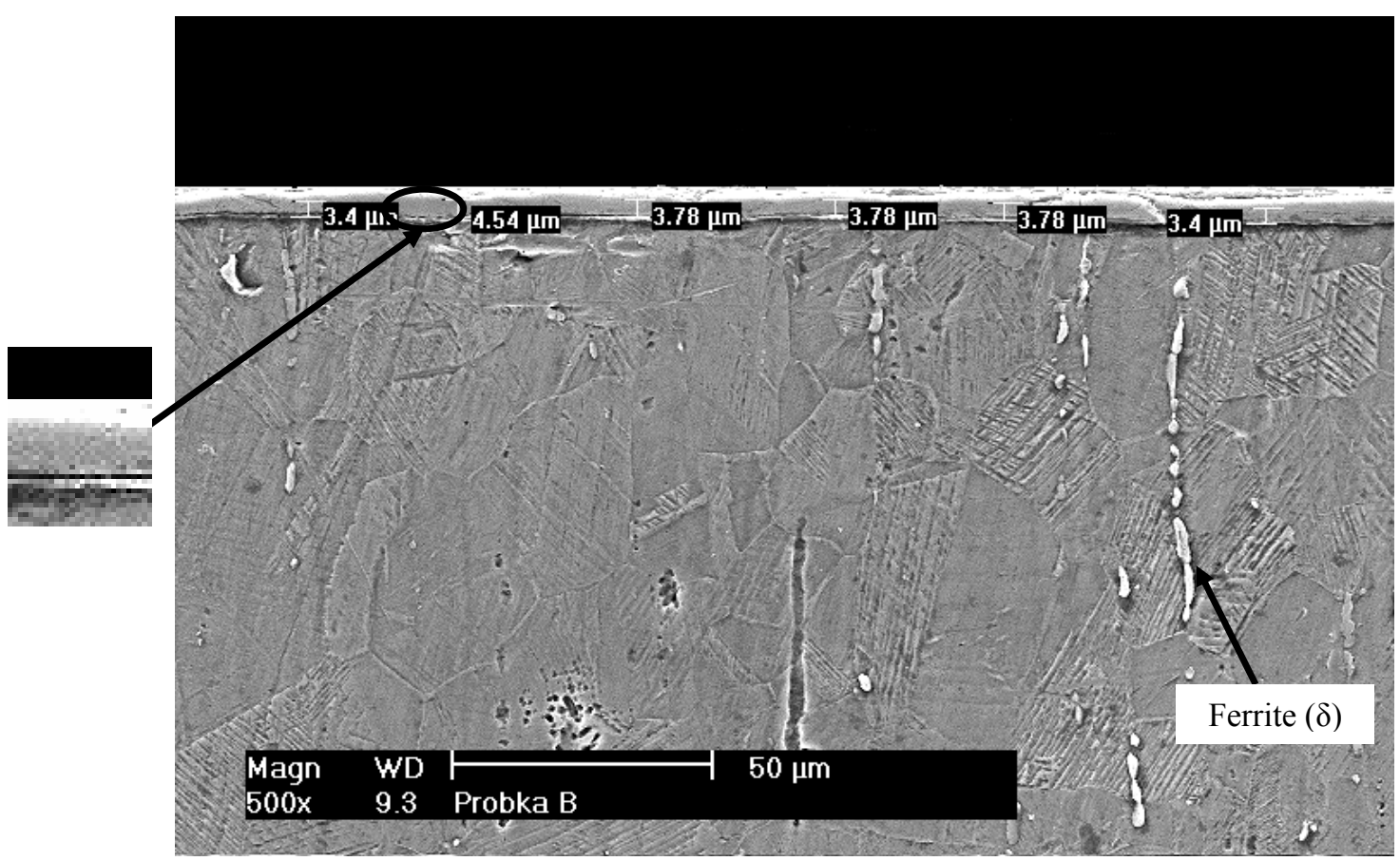

Fig. 1. Cross-section of the nitrided layer (after process no. 1) and the reference material

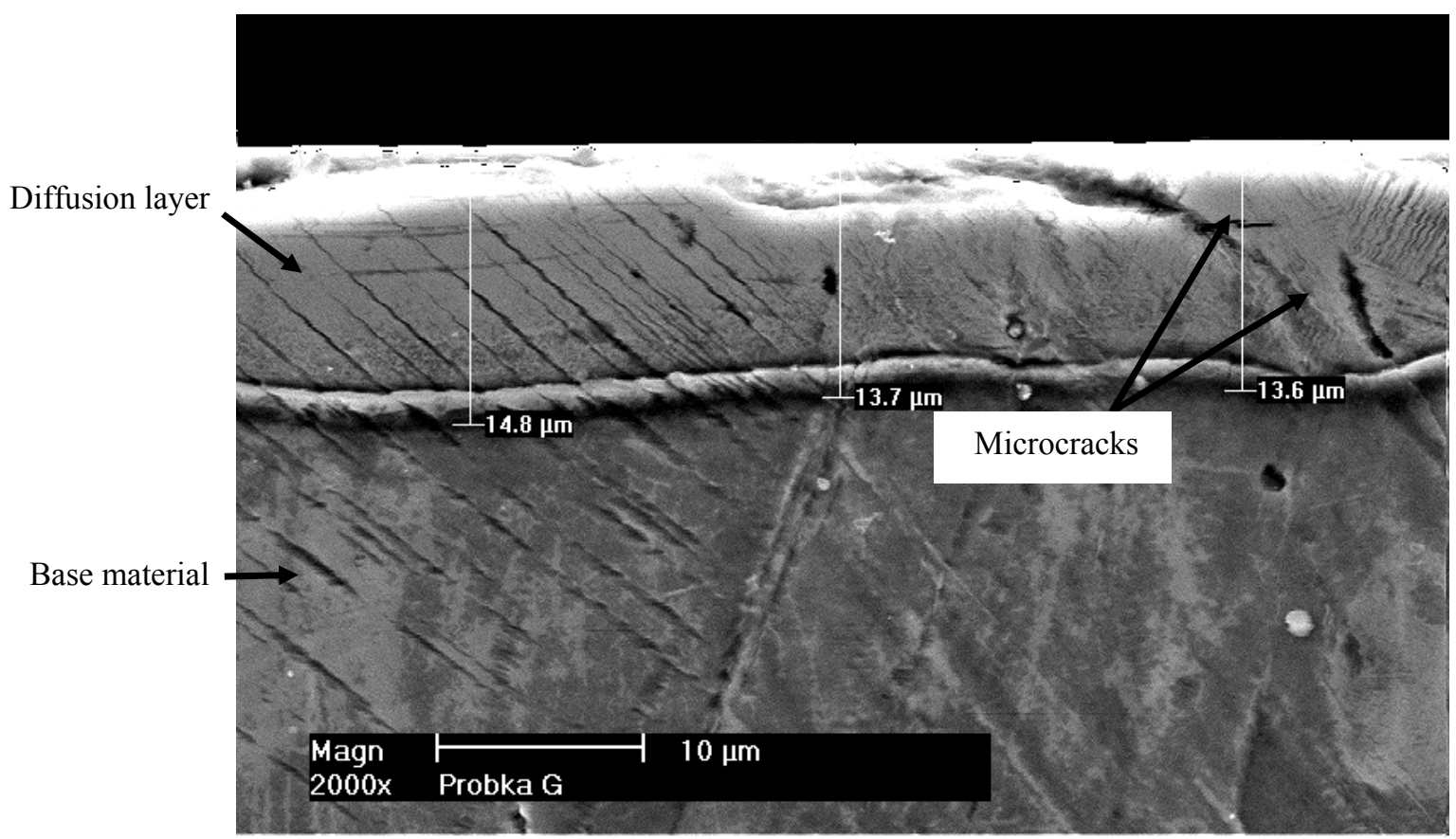

Fig. 2. Cross-section of the nitrided layer (after process no. 2)

In Fig. 3 the microstructure of the remelted layer after the process no. 1a is shown. The cellular microstructure consists of the austenite phase and the delta ferrite phase. Ferrite phase crystallized around the austenite phase. 


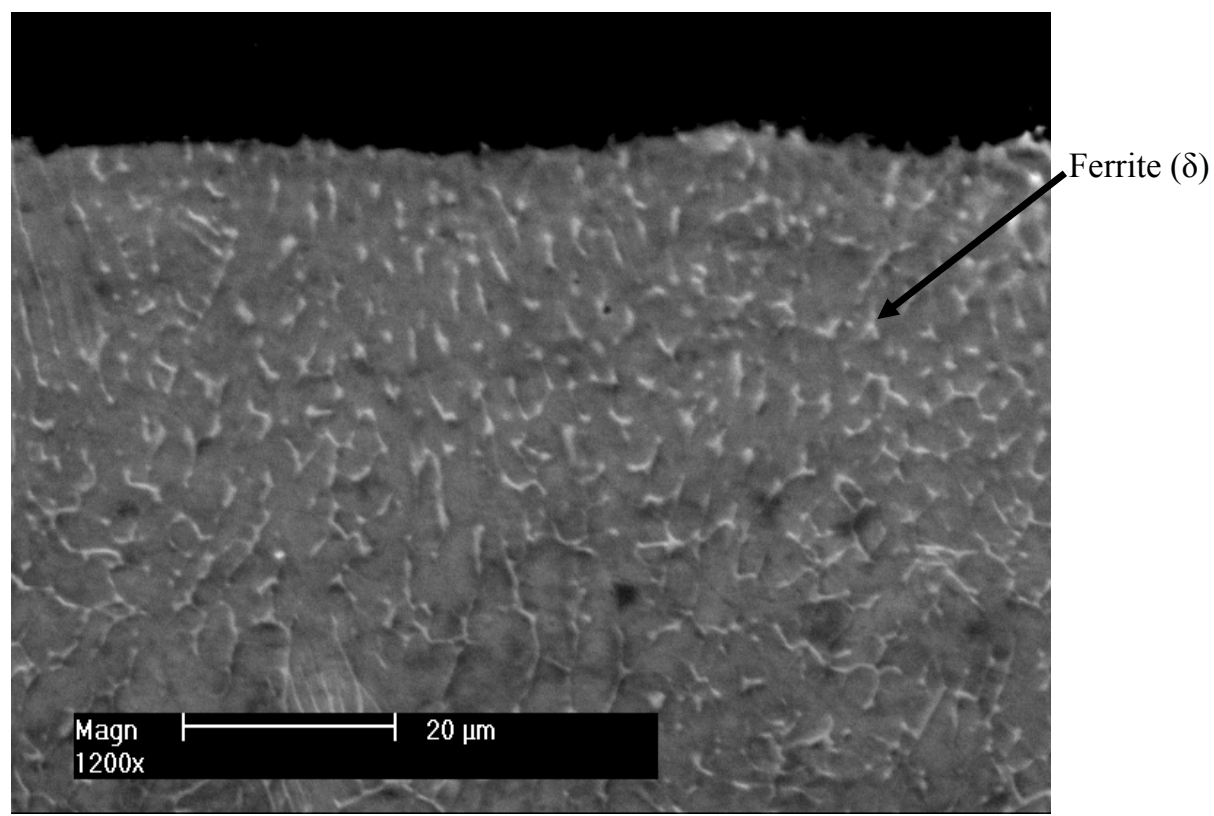

Fig. 3. Cross-section of the remelted layer after process no. 1a

In Fig. 4 the microstructure of the remelted layer after the process no. $1 \mathrm{~b}$ is shown. The higher power of the laser beam has led to columnar microstructure consisting of austenite dendrites, which have grown epitaxially from the base material. Planar front solidification zone has appeared in the bottom of the laser-melted track due to low solidification rate and the steep temperature gradients in this region.

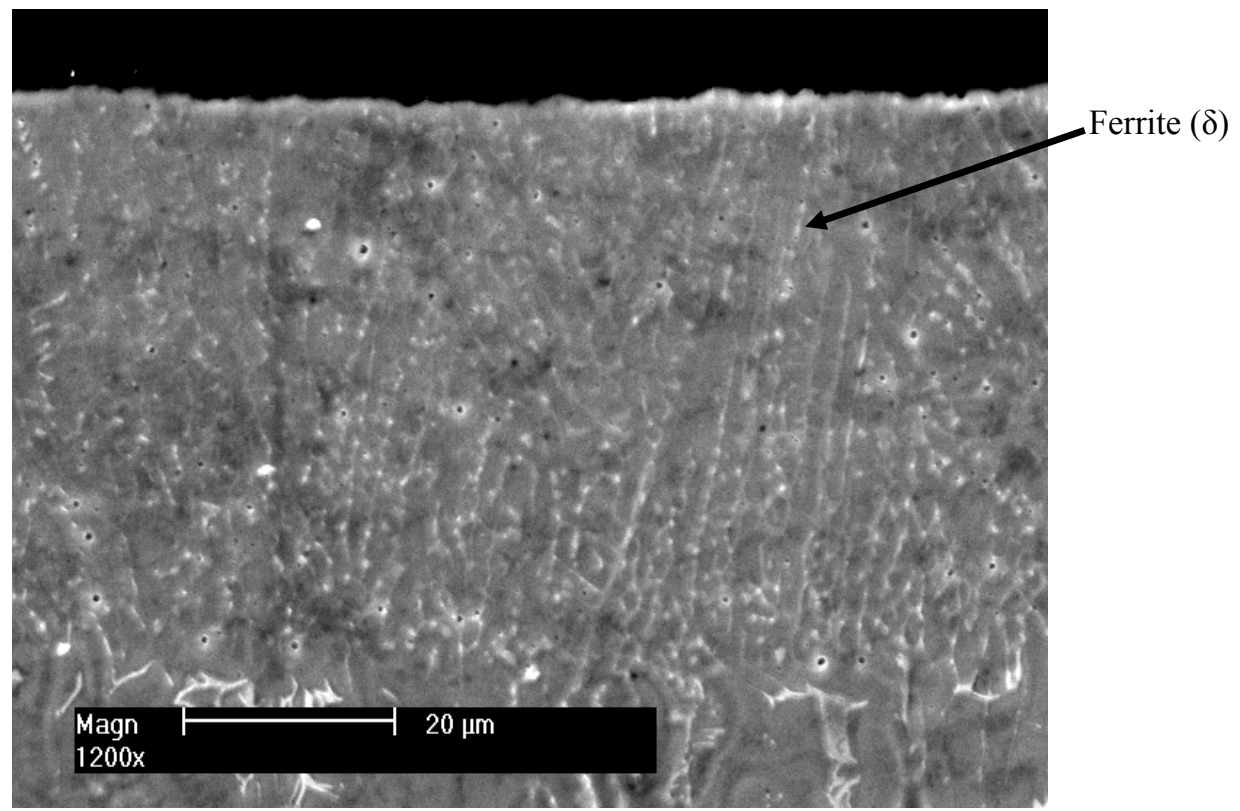

Fig. 4. Cross-section of the remelted layer after process no. $1 \mathrm{~b}$ 


\section{Nanoindentation tests}

The investigations of mechanical properties were carried out using an Ultra Nanoindentation Tester (UNHT) in the Institute of Fundamental Technological Research of the Polish Academy of Sciences. The indentation tests were carried out according to the method of Olivier and Pharr as described in reference [1]. The measurements of mechanical properties proceeded in a repeatable and automated mode. The measurements were conducted in a single load/unload cycle. During the cycle the maximum loads were 20 or $50 \mathrm{mN}$. The loading rate was set to $40 \mathrm{mN} / \mathrm{min}$ in all the tests. The maximum loads were applied for periods of $1 \mathrm{~s}(20 \mathrm{mN})$ and $2 \mathrm{~s}(50 \mathrm{mN})$ duration. The investigations were carried out using a Berkovich indenter. The results were automatically obtained in Vickers hardness scale.

In Fig. 5 representative dependence between the load value and the displacement of the indenter in nitrided layers is shown. The results were compared with those of the reference material (not nitrided). All the investigations of nitrided layers and the reference material were examined using two different maximum loads: 20 and $50 \mathrm{mN}$.

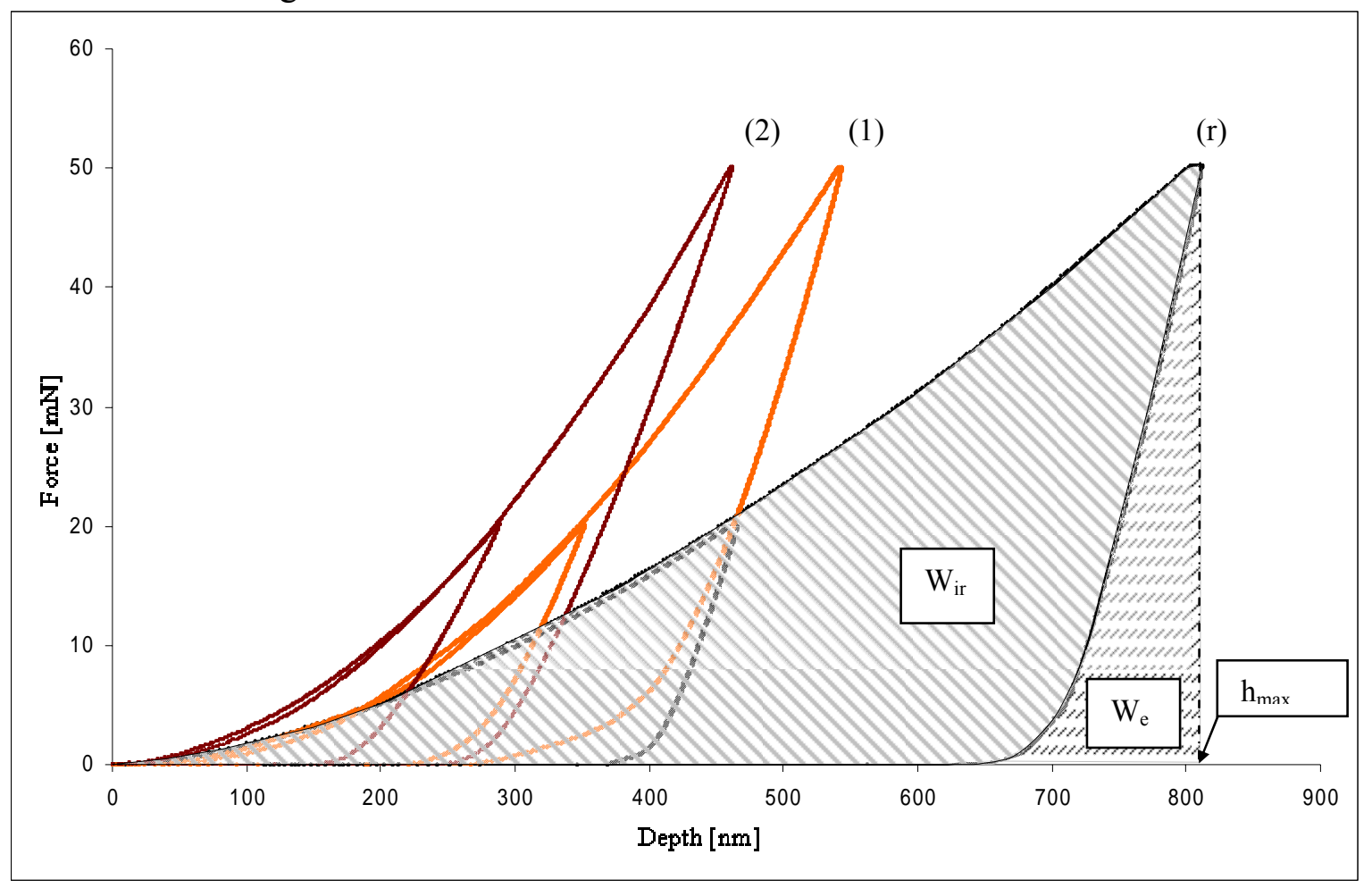

Fig. 5. Force - indentation depth curves measured on the surface of nitride layers after processes: no. 1 (1), no. 2 (2). Results were compared with the reference material ( $r$ )

The values of the Vickers hardness (HV), the irreversible indentation work $\left(\mathrm{W}_{\mathrm{ir}}\right)$, the reversible work $\left(\mathrm{W}_{\mathrm{e}}\right)$ and the maximum depth $\left(\mathrm{h}_{\max }\right)$ during the indentation are shown in tab. 3. The values of standard deviations calculated from three independent measurements are given in brackets.

The results of the investigations indicated a significant effect of termochemical treatment on the indentation curves in case of nitride layers. The nitrided layers independent of chemical composition of the gas mixture during the nitriding process have shown higher values of hardness in comparison with the reference material. Moreover, it was observed that the higher nitrogen content in the gas mixture during the nitriding affected the hardness of diffusion layers. 
In reference [17] it has been shown that the chemical composition of the gas mixture during the nitriding process has a significant effect on phase constitution of austenitic stainless steels. It was observed that the nitrogen content in the gas mixture higher than $30 \%$ causes separation from the solution of chromium nitrides. Moreover, in paper [18] it has been confirmed that the higher nitrogen content in the gas mixture does not have an impact on the maximum nitrogen content in the nitrided layers. The cited research indicates that the main factors which exert an influence on the increase of hardness and the decrease of irreversible indentation work $\left(\mathrm{W}_{\mathrm{e}}\right)$ are: phase $\mathrm{S}$ and the precipitates in the superficial zone.

Table 3. Results of indentation tests at surface of the samples

\begin{tabular}{|c|c|c|c|c|c|c|c|c|}
\hline \multirow{2}{*}{ Type of layer } & \multicolumn{4}{|c|}{ Maximum force $20[\mathrm{mN}]$} & \multicolumn{4}{c|}{ Maximum force 50 [mN] } \\
\cline { 2 - 9 } & $\begin{array}{c}\mathrm{W}_{\mathrm{e}} \\
{[\mathrm{pJ}]}\end{array}$ & $\begin{array}{c}\mathrm{W}_{\mathrm{ir}} \\
{[\mathrm{pJ}]}\end{array}$ & $\begin{array}{c}\mathrm{h}_{\max } \\
{[\mathrm{nm}]}\end{array}$ & $\mathrm{HV}$ & $\begin{array}{c}\mathrm{W}_{\mathrm{e}} \\
{[\mathrm{pJ}]}\end{array}$ & $\begin{array}{c}\mathrm{W}_{\mathrm{ir}} \\
{[\mathrm{pJ}]}\end{array}$ & $\begin{array}{c}\mathrm{h}_{\max } \\
{[\mathrm{nm}]}\end{array}$ & $\mathrm{HV}$ \\
\hline \multirow{2}{*}{ Diffusive (1) } & 915 & 1342 & 339 & 1059 & 4088 & 5011 & 547 & 1069 \\
$(38)$ & $(28)$ & $(9)$ & $(76)$ & $(240)$ & $(60)$ & $(8)$ & $(44)$ \\
\hline \multirow{2}{*}{ Diffusive (2) } & 996 & 1056 & 286 & 1730 & 4095 & 4021 & 469 & 1653 \\
& $(2)$ & $(14)$ & $(4)$ & $(59)$ & $(59)$ & $(169)$ & $(6)$ & $(22)$ \\
\hline \multirow{2}{*}{ Remelted (1a) } & 644 & 3073 & 488 & 433 & 2461 & 14500 & 862 & 346 \\
$(30)$ & $(166)$ & $(6)$ & $(20)$ & $(113)$ & $(554)$ & $(31)$ & $(23)$ \\
\hline \multirow{2}{*}{ Remelted (1b) } & 661 & 3242 & 494 & 430 & 2493 & 13436 & 807 & 408 \\
& $(32)$ & $(86)$ & $(7)$ & $(19)$ & $(280)$ & $(505)$ & $(33)$ & $(21)$ \\
\hline \multirow{2}{*}{ Reference material (r) } & 645 & 2850 & 459 & 489 & 2634 & 12787 & 804 & 388 \\
$(17)$ & $(95)$ & $(7)$ & $(32)$ & $(174)$ & $(514)$ & $(8)$ & $(10)$ \\
\hline
\end{tabular}

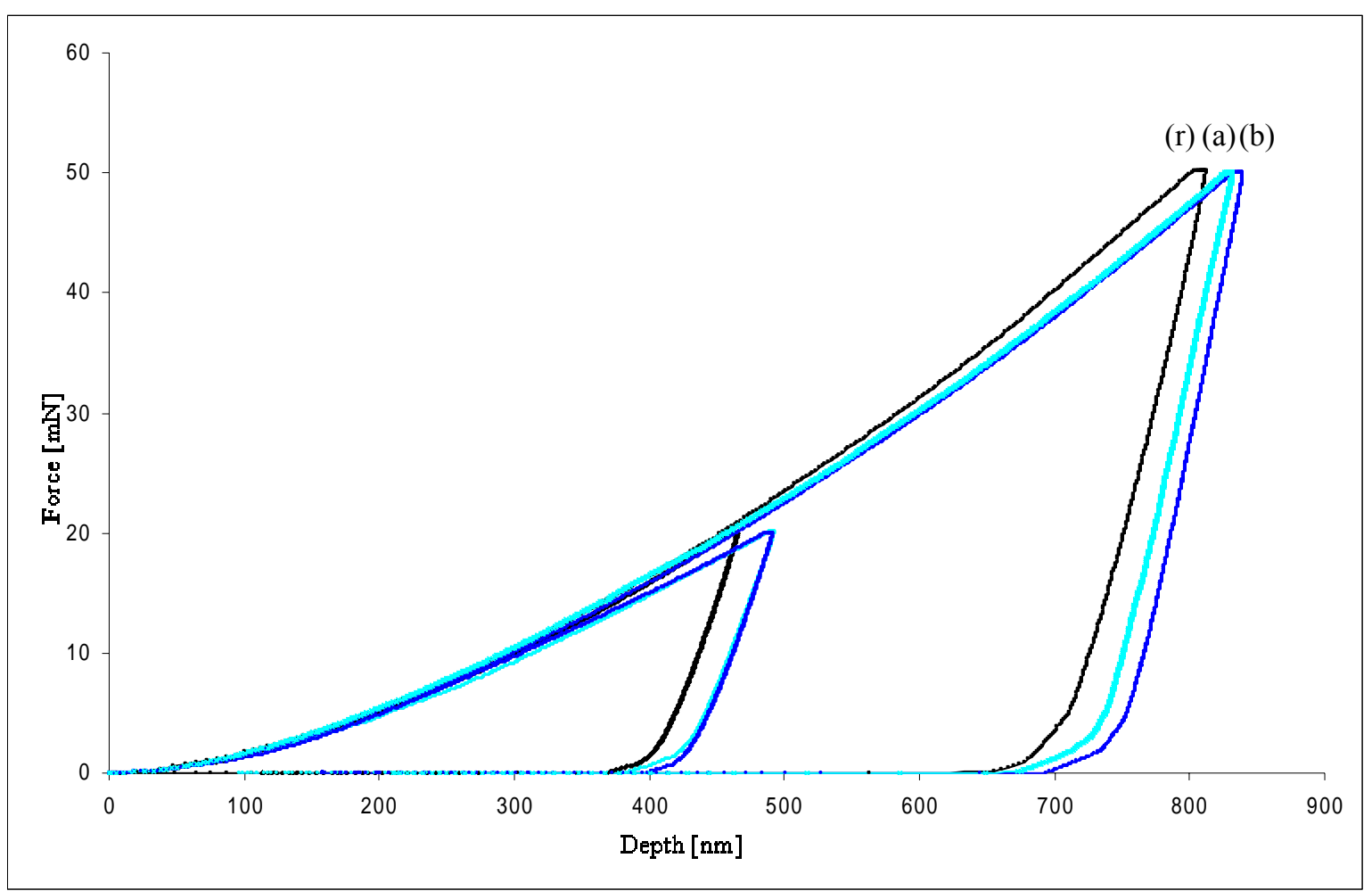

Fig. 6. Force - indentation depth curves measured on the surface of remelted layers obtained by using different power of laser beam: $P=2 \mathrm{~kW}(1 \mathrm{a}), \mathrm{P}=5 \mathrm{~kW}(1 \mathrm{~b})$. Results are compared with those of the reference material $(r)$

In Fig. 6 representative dependence between the volume of load and the displacement of the indenter in the remelted layers is shown. The results are compared with those of the 
reference material. The remelted layers and the reference material were examined using two different maximum loads: 20 and $50 \mathrm{mN}$.

The results of the layers remelted after the laser treatment do not reveal any important influence of the processing applied. In case of the laser remelting the hardness of the remelted layers is close to that of the reference material. The differences are negligible and depend on the distribution of the delta ferrite in austenitic microstructure (table 3 ).

\section{Ductility and elasticity index}

On the basis of mechanical properties, the ductility $\left(\mathrm{I}_{\mathrm{ir}}\right)$ and elasticity $\left(\mathrm{I}_{\mathrm{e}}\right)$ indexes have been calculated from the following equations:

$$
\mathrm{I}_{\mathrm{ir}}=\frac{\mathrm{W}_{\text {ir }}}{\mathrm{W}_{\mathrm{t}}} \quad \mathrm{I}_{\mathrm{e}}=\frac{\mathrm{W}_{\mathrm{e}}}{\mathrm{W}_{\mathrm{t}}}
$$

where: $\mathrm{W}_{\mathrm{t}}=\mathrm{W}_{\mathrm{ir}}+\mathrm{W}_{\mathrm{e}}, \mathrm{W}_{\mathrm{t}}-$ total indentation work

In table 4 the values of elasticity and ductility indexes are shown. The highest elasticity index values were obtained for two diffusion layers whereas the lowest values were noted for the remelted layers and the reference material.

Table 4. The values of ductility and elasticity index

\begin{tabular}{|c|c|c|}
\hline Type of layer & Ductility index $\left(\mathrm{I}_{\text {ir }}\right)$ & Elasticity index $\left(\mathrm{I}_{\mathrm{e}}\right)$ \\
\hline Diffusion (1) & $59 \%$ & $51 \%$ \\
\hline Diffusion (2) & $51 \%$ & $49 \%$ \\
\hline Remelted (1a) & $83 \%$ & $17 \%$ \\
\hline Remelted (1b) & $83 \%$ & $17 \%$ \\
\hline Reference material (r) & $82 \%$ & $18 \%$ \\
\hline
\end{tabular}

\section{Cavitation erosion test at the vibratory rig}

The investigation of the material and the processed surface layer resistance to cavitation erosion was performed at the vibratory rig with stationary specimen, based on Sonics VCX500 ultrasonic processor. The stand is in compliance with the ASTM G32-03 standard. The vibrations frequency and the peak-to-peak amplitude were $20 \mathrm{kHz}$ and $100 \mu \mathrm{m}$, respectively. Furthermore, the distance between the vibration horn tip surface and the test specimen surface was $5 \mathrm{~mm}$. According to [19] this corresponds to the power density of $5,6 \mathrm{~W} / \mathrm{cm}^{2}$ at the surface of a specimen. However, it allows to diagnose more accurately the incubation period in the surface layer with thickness under $10 \mu \mathrm{m}$. During the cavitation erosion test, demineralized water was kept at the temperature of 21 to $22{ }^{\circ} \mathrm{C}$ through the cooling ultrathermostatic controller (Polyscience 9512) with external circulation.

In Fig. 7a the general outlook of the stand is shown. In Fig. $7 \mathrm{~b}$ the test vessel without a cooling system is shown. The test specimen cast with a cooling system is shown in Fig. 7c. 
a)

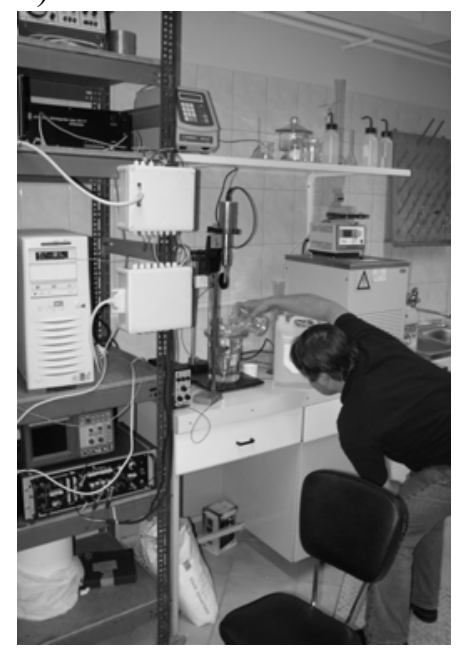

b)

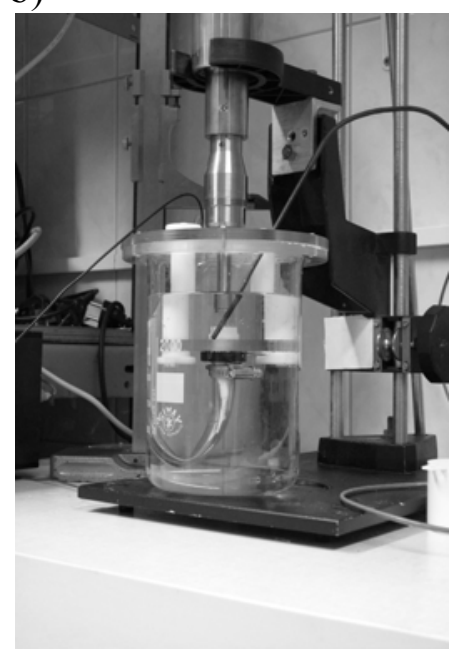

c)

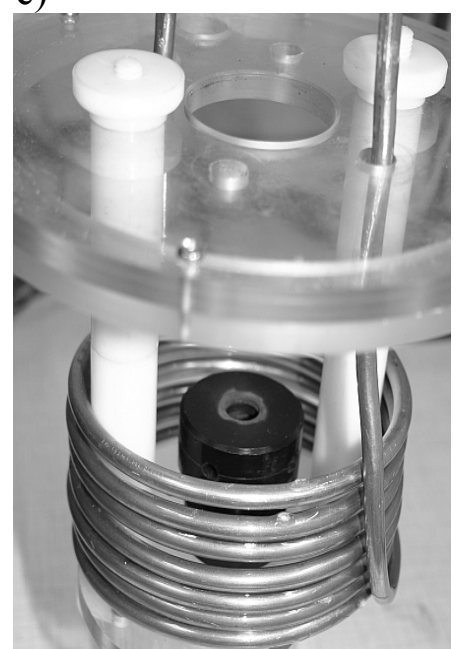

Fig. 7. Vibratory stand: a) general outlook, b) test vessel without a cooling system, c) test specimen cast with a cooling system [19]

In Fig. 8 the surfaces of the reference material and the remelted layer after applying cavitation load at the vibratory rig are presented. In Fig. 8a a lot of deformations caused by cavitation impacts in the reference material are presented. Moreover, a lot of regions in which slip bands occurred can be observed. In Fig. 8b plastic deformations in the remelted layer surface are presented. It was noticed during the cavitation test that eroded areas appeared on these bulges after 1-hour-long exposure to cavitation load.

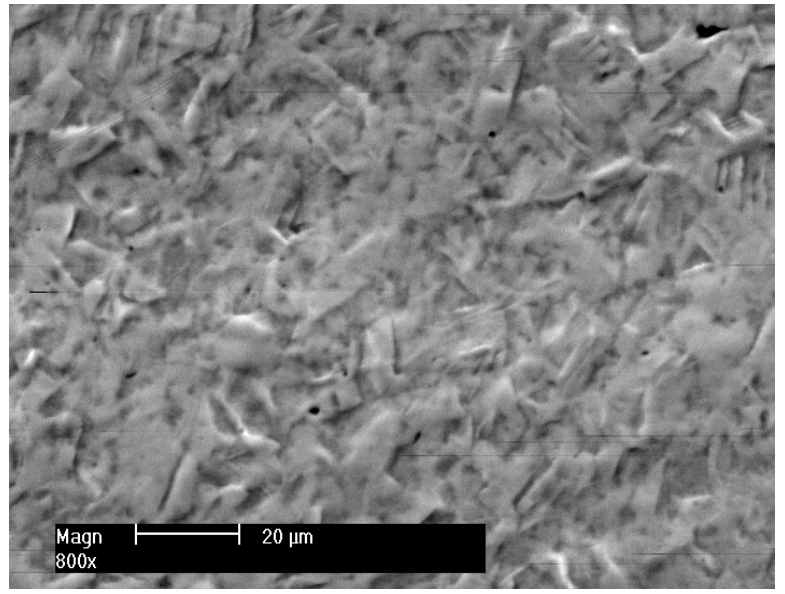

Fig. 8a. Surface of the reference material (60 min. of exposure)

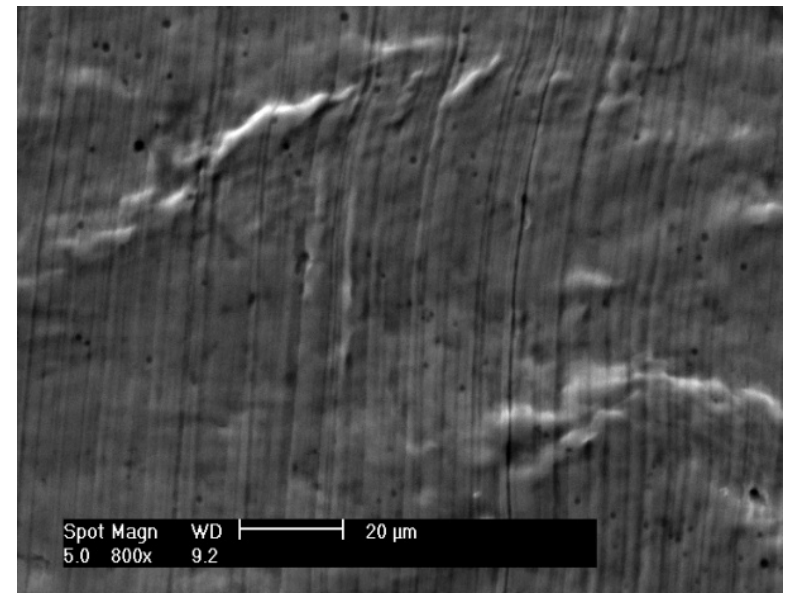

Fig. 8b. Surface of the remelted layer after process no. $1 \mathrm{a}$ (60 min. of exposure)

In Fig. 9 the surfaces of the nitrided layers after the cavitation tests are presented. In case of the diffusion layer after the process no. 1, eroded areas are observed in grain boundaries (Fig. 9a). In case of the diffusion layer obtained in result of the process no. 2, brittle fractures are observed in the initial stages of cavitation load (Fig. 9b).

In Fig. 10 erosion cavitation curves are presented. 


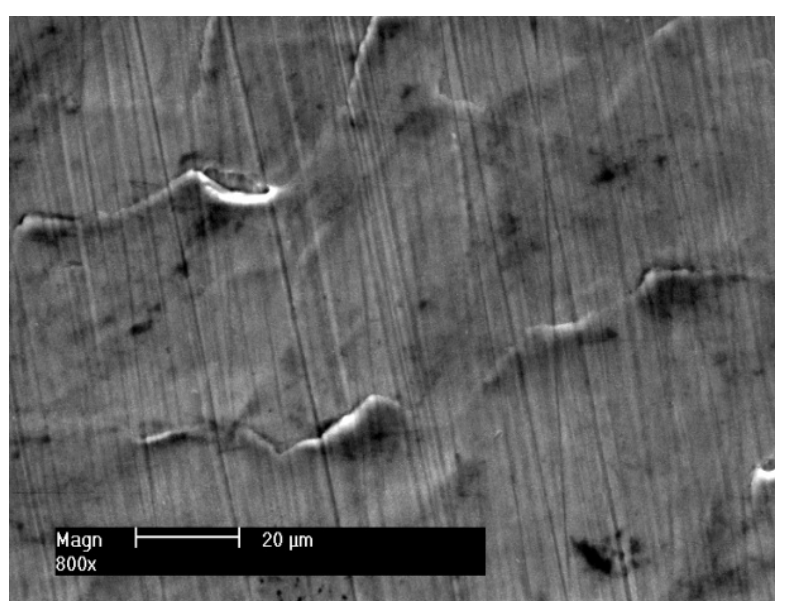

Fig. 9a. Surface of the nitrided case after process no. 1 (90 $\mathrm{min}$. of exposure)

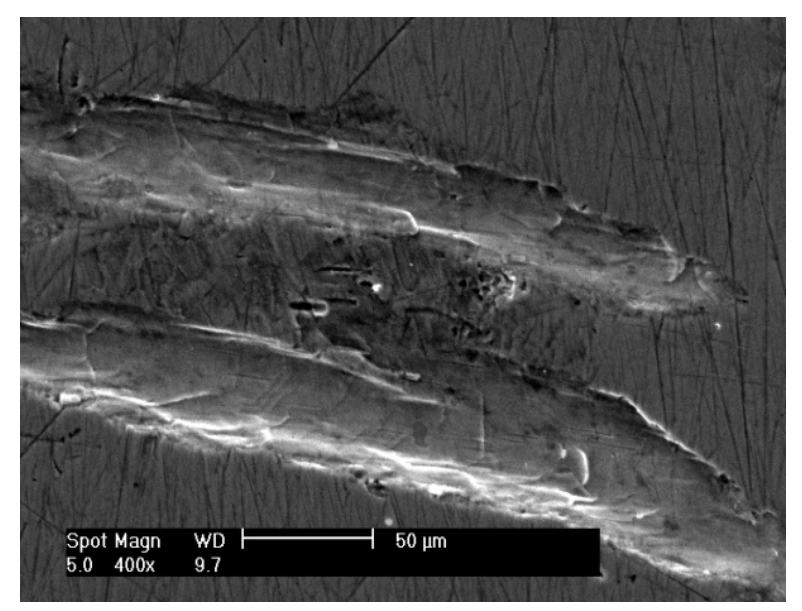

Fig. 9b. Surface of the nitrided case after process no. 2 (10 min. of exposure)

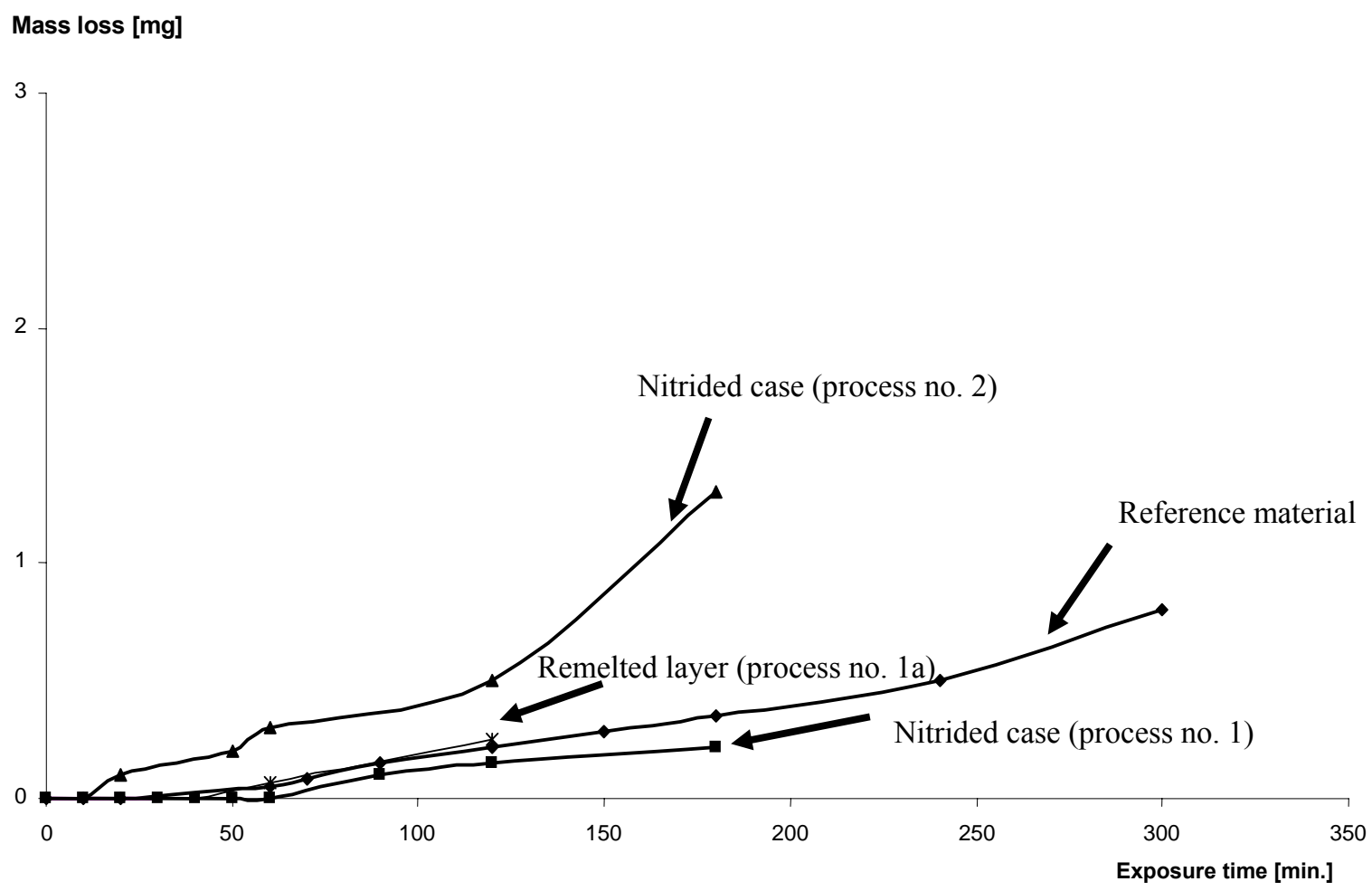

Fig. 10. Cavitation erosion curves obtained at the vibratory rig

Having compared the presented curves, it is obvious that the nitrided layer after process no. 1 is characterized by the highest resistance to cavitation erosion. In case of the diffusion layer obtained by applying the above mentioned process, the resistance to cavitation erosion is higher than that of the reference material and the remelted layer. The diffusion layer after process no. 2 has shown the lowest resistance which has resulted in the highest mass loss. Brittle fractures in the initial stages of cavitation load application are responsible for such a loss. 


\section{CONCLUSIONS}

1. The glow-discharge nitriding process influences material properties. Nitrided layers have increased the Vickers hardness (HV), the reversible indentation work $\left(\mathrm{W}_{\mathrm{e}}\right)$, but decreased the irreversible indentation work $\left(\mathrm{W}_{\text {ir }}\right)$ and the maximum depth of the imprint during the indentation tests.

2. The increase of nitrogen content in the gas mixture during the glow-discharge nitriding process at the temperature $450^{\circ} \mathrm{C}$ has caused an increase in the values of Vickers hardness and reversible work $\left(\mathrm{W}_{\mathrm{e}}\right)$ in comparison to the reference material.

3. The remelting process has not influenced material properties. The observed changes have been insignificant independently of the parameters of laser treatment.

4. The nitriding process no. 1 has led to microstructure consisting of $\mathrm{S}$ phase (it has been proven in reference [17]), which may be beneficial to lengthening of austenitic stainless steels exploitation period under cavitation conditions.

5. It has been proven that the layers with higher elasticity index, hardness and microstructure consisting of S phase improve cavitation erosion resistance of austenitic stainless steels.

\section{REFERENCES}

1. Oliver W., Pharr G.: An improved technique for determining hardness and elastic modulus using load and displacement sensing indentation experiments. Journal of Materials Research 7 (1992), 1564-1583.

2. Kwok C., Man H., Cheng F.: Cavitation erosion and pitting corrosion of laser surface melted stainless steels. Surface and Coatings Technology, 99 (1998), 295-304.

3. Conde A., Colaco R., Vilar R., Damborenea J.: Corrosion behaviour of steels after laser surface melting. Materials and Design, 21, (2000), 441-445.

4. Khalfallah I., Rahoma M., Abboud J., Benyounis K.: Microstructure and corrosion behaviour of austenitic stainless steel treated. Optics \& Laser Technology, 43 (2011), 806-813.

5. McCafferty E., Moore P.: Corrosion behavior of laser-surface melted and laser-surface alloyed steels. Journal of the Electrochemical Society, 133 (1986), 1090-1096.

6. Akgun O., Inal O.: Laser surface melting and alloying of 304L stainless steel: Part II. Corrosion and Wear Resistance Properties. Journal of Materials Science, 30 (1995), 6105-6112.

7. Liang W., Xiaolei X., Zhiwei Y., Zukun H.: Low pressure plasma arc source ion nitriding of austenitic stainless steel. Surface and Coatings Technology, 124 (2000), 93-96.

8. Liang W., Xiaolei X., Jiujun X., Yaqin S.: Characteristic of low pressure plasma arc source ion nitrided layer on austenitic stainless steel at low temperature. Thin Solid Films, 391 (2001), 11-16.

9. Borowski T., Trojanowski J., Sobiecki R., Wierzchoń T.: Low temperature glow-discharge nitriding of austenitic steel - medicine applification aspects. Surface Engineering, 3 (2005), 21-26.

10. Trojanowski J., Kamiński M., Wierzchoń T.: Niskotemperaturowe azotowanie stali austenitycznych w warunkach wyładowania jarzeniowego. Inżynieria powierzchni, 2 (2002), 3-10.

11. Sobiecki J., Brojanowska A., Kazior J., Wierzchoń T.: The structure and corrosion resistance of sinters form 316L steel after plasma nitriding. Inżynieria Materiałowa, 5 (2006), 1232-1235.

12. Sobiecki J., Kazior J., Wierzchoń T.: Low temperature plasma nitriding of sintered austenitic steel. Inżynieria Materiałowa, 5 (2005), 434-436. 
13. Trojanowski J., Senatorski J.: Opracowanie technologii azotowania jarzeniowego stali typu 316L. Sprawozdanie Nr 13.2.01.230. Instytutu Mechaniki Precyzyjnej, 2006.

14. Li C. X., Bell T.: Corrosion properties of active screen plasma nitrided 316 austenitic stainless steel. Corrosion Science, 46 (2004), 1527-1547.

15. Yasumaru N.: Low temperature ion nitriding of austenitic stainless steels. Materials Transactions, 39 (1998), 1046-1052.

16. Poirier L., Corre Y., Lebrun J.: Solutions to improve surface hardness of stainless steels without loss of corrosion resistance. Surface Engineering, 18 (2002), 439-442.

17. Sitko A., Szkodo M., Gazda M.: The Characteristic of Surface Layers on Austenitic Stainless Steel After Glow-discharge Nitriding Process. Solid State Phenomena, Vol. 165 (2010), 165-168.

18. Sitko A., Szkodo M., Gazda M.: The Influence of Gas Mixture in the Glow-discharge Nitriding Process of Austenitic Stainless Steel on Characteristic of Nitrided Cases. Key Engineering Materials, Vol. 490 (2012), 282-287.

19. Chmiel J., Janicki W., Krella A., Steller J.: Cavitation loading tests at the vibration stand with the resting sample. Problemy eksploatacji, 1, (2010), 91-100. 